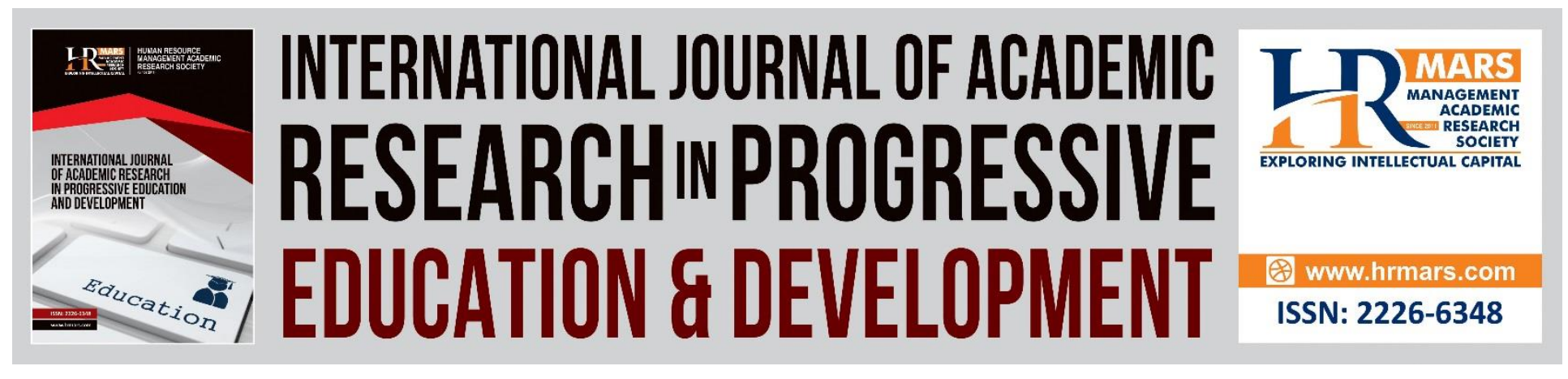

\title{
Module of Cognitive Behavior Play Therapy on Decision Making Skills and Resilience Enhancement (CBPT Module)
}

Nor Hamizah Ab Razak, Ku Suhaila Ku Johari, Mohd Izwan Mahmud, Nadziroh Md Zubir, Sabihah Johan

To Link this Article: http://dx.doi.org/10.6007/IJARPED/v7-i4/4846

DOI: $10.6007 /$ IJARPED/v7-i4/4846

Received: 13 Sept 2018, Revised: 21 October 2018, Accepted: 03 Nov 2018

Published Online: 17 Nov 2018

In-Text Citation: (Razak, Johari, Mahmud, Zubir, \& Johan, 2018)

To Cite this Article: Razak, N. H. A., Johari, K. S. K., Mahmud, M. I., Zubir, N. M., \& Johan, S. (2018). Module of Cognitive Behavior Play Therapy on Decision Making Skills and Resilience Enhancement (CBPT Module). International Journal of Academic Research in Progressive Education and Development, 7(4), 179-199.

Copyright: (C) 2018 The Author(s)

Published by Human Resource Management Academic Research Society (www.hrmars.com)

This article is published under the Creative Commons Attribution (CC BY 4.0) license. Anyone may reproduce, distribute, translate and create derivative works of this article (for both commercial and non-commercial purposes), subject to full attribution to the original publication and authors. The full terms of this license may be seen

at: http://creativecommons.org/licences/by/4.0/legalcode

Vol. 7, No. 4, 2018, Pg. 179 - 199

http://hrmars.com/index.php/pages/detail/IJARPED

JOURNAL HOMEPAGE

Full Terms \& Conditions of access and use can be found at http://hrmars.com/index.php/pages/detail/publication-ethics 


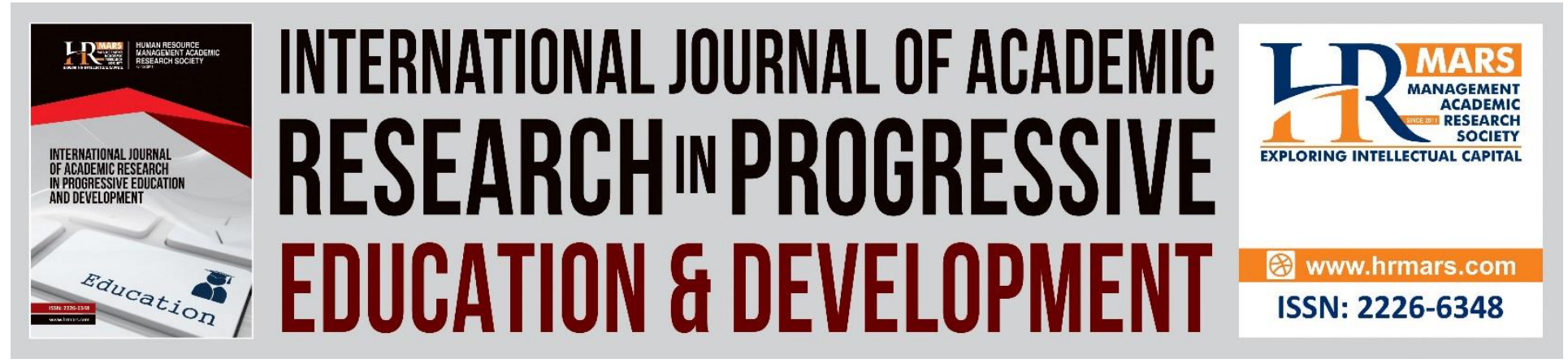

\title{
Module of Cognitive Behavior Play Therapy on Decision Making Skills and Resilience Enhancement (CBPT Module)
}

\author{
Nor Hamizah Ab Razak, Ku Suhaila Ku Johari, Mohd Izwan \\ Mahmud, Nadziroh Md Zubir, Sabihah Johan \\ Faculty of Education, Universiti Kebangsaan Malaysia, 43600 Bangi, Selangor, Malaysia.
}

\begin{abstract}
Gifted and talented students have high intellectual, creativity and problem-solving skills. However, these groups tend to have issues related to social and emotional issues. Decision making skills and resilience are necessary elements in helping these groups deal with the social and emotional issues faced effectively. This study aims to produce a structured module based on Cognitive Behavior Play Therapy by making the Sidek's Module Development Model as a guide in its development process. The contents of the module are based on critical and analytical literature review. The draft module consists of six sub modules: Movement Therapy, Art Therapy, Clay Therapy, Sand Therapy, Music Therapy and Puppet Therapy. The sub module is broken down into 14 activities and six units. It is proposed that further studies to be conducted to see the validity and reliability of this module.

Keywords: Gifted And Talented Students, Decision Making Skills, Resilience, Cognitive Behavior Play Therapy, Sidek's Module Development Model.

\section{Introduction}

Gifted and talented students (GTS) are individuals who do not have only the cognitive ability, creativity and commitment but also ability to solve problems (Rorlinda, 2014). Meanwhile, Gagne (2009) defines GTS as individuals who have the potential or natural potential and these abilities can be developed into talents through the environment and other factors. The talented individual's natural ability includes mental abilities that cover intellectual, creativity, social affective and perceptual aspects as well as physical abilities that include the sensorimotor aspect. Meanwhile, according to Noriah and Abu Yazid (2010), GTS is a country asset that needs to be educated and needs to be identified for the potential of excellence they can contribute. Thus, the strengths and abilities that may be fully utilized then can be contributed to the country's reputation.
\end{abstract}


Vol. 7, No. 4, 2018, E-ISSN: 2226-6348 ๑ 2018 HRMARS

Although this group is better known by its advantages, the fact is that this group still behaves like ordinary child or teenager who has social and emotional issues (Abu Yazid, 2015). The statement supports the view of Blaas (2014), Rorlinda (2014), Noriah \& Abu Yazid (2010) and Touron, Touron \& Silvero (2005) who are also often associated this group with social and emotional issues. The findings from domestic and foreign research also reveal issues related to this group such as frustration, anxiety, irritability, boredom, social isolation, emotional stress, difficulty in making friendship because of the concept of friendship that is precarious, lack of motivation, low self-concept, social denial, low emotional awareness and difficult to control, difficulty in communicating with lower-level IQ peers, loneliness, phobia, interpersonal problems, perfectionist, lack of resilience, fear of failure and avoid risk due to the need for high perfection and depression, especially among the highly creative GTS (Perrone-McGovern et al. 2015; Versteynen, 2013; Rosadah \& Aliza, 2010; Neihart, Reis, Robinson, Moon, 2002).

Therefore, studies on the GTS need to cover a variety of dimensions, particularly in the cultivation and enhancement of certain skills and also provide strong self-defense in the face of challenges as a smart and talented individual today and in the future. In that regard, counseling services are advised to act in forming and improving decision making skills as well as resilience as it is highly coherent to be applied among GTS. This is because decision making skills are the skills used in any situation (Zakri \& Saemah, 2015; Greenbank, 2010) especially when dealing with social and emotional issues (Masureik et al., 2014). While high resilience is seen as a defense fortress that acts as the strength of the GTS to remain steadfast and resilient (Cazan \& Dumitrescu, 2016) as these groups cannot escape the challenges of life.

\section{Problem Statement}

Although studies on GTS are increasingly gaining attention in education, they are limited to cognitive aspects while ignoring their social and emotional aspects (Rorlinda et al., 2016). This is because, GTS is often misinterpreted as the perfect individual of all aspects. Furthermore, these groups do not being given special education programs and guidance (Gallagher \& Gallagher, 1994; Amini, 2005) by the school and with assumption that the interpersonal ability they possess is sufficient to help them dealing with problems or difficulties experienced (Amini, 2005).

In fact, the GTS is as well as ordinary students who cannot escape from psychological issues. The situation is due to psychological and environmental factors such as asynchronous development, high expectations from various parties, often unobtrusive learning and difficulty adapting to social interactions (Scott, 2012; Aliza\& Hamidah, 2009). Obviously, the issues faced by the GTS involve a lot of social and emotional components that will contribute to low selfesteem, low self-motivation, unable to achieve to their true potential (underachiever) and anxiety issues. Failure to address social and emotional issues can affect the potential development of the natural intelligence of GTS. Hence, knowledge and psychological awareness will contribute to the development of self-potential to a maximum level in accordance with acquired intelligence.

Based on the discussion, it shows that the GTS needs appropriate knowledge and skills in addressing the social and emotional issues faced. In tackling the issues, decision making skills and resilience are important. There are many studies on decision making skills among GTS, but focus 

DEVELOPMENT

Vol. 7, No. 4, 2018, E-ISSN: 2226-6348 ๑ 2018 HRMARS

is only on aspects of career choices (Ogurlu, Rich \& Hizli, 2015; Ozcan, 2017). The skills also have a close relationship with one's resilient ability (Coscun et al., 2014) which is indispensable in the face of social and emotional issues among GTS (Cazan \& Dumitrescu, 2016) and thus making them strong in facing challenges live. Hence, having the skills of decision making and resilience has great implications of addressing the social and emotional issues and further developing at optimum levels.

In this regard, the counseling services needs to be more proactive in assisting the development of GTS in Malaysia. Looking at the development of these groups, counselors should offer different counseling services than ordinary teens. Mahoney (2011) proposes a creative approach in addressing GTS issues as it takes into account the uniqueness and cognitive development of this group. Among the appropriate creative approaches applied to the GTS are play therapy. However, play therapy is still not widely available in Malaysia (Ku Suhaila et al., 2014) and makes this approach less applied by counselors in Malaysia. In addition, there is no play therapy module in the counseling process that can be used as a reference source for counselors in handling these problems. Hence, researcher is called upon to undertake the responsibility of building play therapy modules in order to improve their decision making skills and resilience among GTS.

\section{Literature Review}

Play Therapy

Play Therapy is one of the ideal approaches to helping children with mental health issues. It is a form of therapeutic method to help children understand and address the psychosocial issues faced. According to Axline (1969), children cannot express their problems and dissatisfaction verbally, but instead express it during play. Additionally, Landreth (2002) also pointed out that while playing children can play their feelings, even better than the real situation. This is because children feel more confident and able to control real life through play. At the same time, children also release negative emotions gradually forming self-esteem that is also the most important aspect of positive self-development.

Many previous studies have proven the effectiveness of play therapy especially in treating children's behavioral and emotional problems. Bratton et al. (2005) found that play therapy is suitable for use in various situations, age, gender, population and in various clinical and nonclinical situations. They also find effective play therapy in shaping the behavior, social adaptation and personality of children. It is an essential element of holistic development in children.

Although the play therapy has long been practiced in the West as early as the 1990s, however, in Malaysia this therapy is a relatively new approach and its use is still limited (Ku Suhaila et al., 2014). However, lately, Malaysian society, especially the counselling practitioners are increasingly aware of the importance of play therapy against children. This has been proven by the existence of studies on play therapy in the Malaysian context as analyzed by Mariani \& Asnarulkhadi (2016), Ku Suhaila et al. (2014), Kuet (2014), Busu \& Rusli (2014) and Salina Nen (2014). 


\section{Decision making Skills}

Decision making is a critical cognitive process for every corner in the life of an individual. Through this process, each individual plays an active role and gets positive results if the skills are working well (Colakkadioglu, 2016). Meanwhile, most previous researchers define decision making as the process of selecting one possibility from other possibilities (Miller \& Byrnes, 2001; Rehman \& Khan, 2015). Earlier, this skill was regarded as a skill that cannot be taught and is believed to be formed in parallel with time travel and age development. On the other hand, some studies have shown that the decision making skills are the skills they can learn (Taal \& De Carvalho, 1997; Klaczynski et al., 2001; Mincemoyer \& Perkins, 2003).

In addition, this skill is very important in the life of every individual as decision making is one of the activities performed daily. Decisions also affect the life of an individual. The study of Colakkadioglu (2016) found that having decision making skills can enhance the level of selfesteem, satisfaction of life and also showcases cognitive functionality through the ability to cope with stress.

Interestingly, research related decision-making among GTS has begun since 1984. Earlier, many psychologists are keen to identify and embed cognitive skills and abilities in children and smart teens. Most of these studies are aimed at identifying the skills that distinguish between smart learners and ordinary students (Davidson \& Sternberg, 1984).

In the meantime, Ball et al. (1994) conducted a study on 12-15 years old students consisting of regular students as well as students from acceleration classes. Among the aspects that are measured are meta-cognitive level and finding that smart learners are more understanding about things that involve decision-making activities. Smart students are also more likely to set goals more specifically, take into account all the options available well, think about what might happen and make a judgment before acting. While, Borkowski \& Peck (1986) found that intelligent learners have meta-cognitive knowledge about learning strategies and memory, a high level of understanding (Devall, 1983; Fehrmbach, 1991), able to differentiate relevant things and irrelevant (Marr \& Stemberg, 1986) and able to solve mathematical problems (Davidson \& Sternberg, 1984).

Additionally, according to Saygili (2014), smart learners have high potential in problem solving. Most GTS are also excited to carry out tasks and work to complete the task perfectly. This group is also more striking than peers in terms of conducting more advanced analysis and also using abstract thinking as well as more effective thinking skills (Ersoy \& Deniz, 2016). Therefore, decision making skills are expected to be more developed among GTS than regular students. This is also supported by Emirdan Acar (2007) who find GTS decision making skills higher than normal students.

However, there are also some studies suggesting that these skills need to be improved among GTS (Milligan, 2004; Mofield et al., 2016; Ozcan, 2017). Meanwhile, Schlichter (1981) also exposed the issues often faced by smart students living in the interior as issues related to self- 
Vol. 7, No. 4, 2018, E-ISSN: 2226-6348 ๑ 2018 HRMARS

esteem, level of aspiration and disappointment. However, the student has the power in terms of logical thinking, problem solving, sensitivity to injustice and interest in relationships and activities. Therefore, Schlichter sees that decision making skills are the necessary skills and are also required in order to balance between the needs and the capabilities of these groups. Additionally, decision making skills are the skills that can be sharpened and polished (Mincemoyer \& Perkins, 2003) in turn make it a necessity to be improved among GTS.

Similarly, Ersoy \& Deniz (2016) who have explained the decision making skills among GTS can be affected by the characteristics of the group itself. For example, the feature of extreme perfection possessed by the GTS puts them in a state of stress and angry when unable to accomplish something as expected and fails to deal with it in a healthy way. This attitude forces the GTS to see something as 'right' or 'wrong' regardless of the difference between 'right' and 'wrong' and ignore alternatives when making decisions. Thus, decision making skills are crucial and can act as strategies in addressing the negative effects of the unique features of extreme perfection as well as helping the GTS to deal with these features in a healthy way.

\section{Resilience}

Resilience means an individual's ability to rebuild from a sad life (Sibert, 2005) and is a fortress in a person exposed to adverse effects or difficulties that the individual can overcome, persist and continue to grow (Chen et al., 2017). The result is that not only is the individual recovered but they often bounce back into being stronger than ever. On the other hand, those with low resilience are difficult to deal with negative emotions and exhibit stress on a particular event (Mak et al., 2011).

Meanwhile, Neihart (2001) suggests smart learners share the same characteristics as resilient students which are high emotional intelligence and curiosity, high self-efficacy, humor and ability to solve problems. In addition, the GTS is also said to have high resilience when the student is able to cope with any challenges including social and emotional issues experienced (Cazan \& Dumitrescu, 2016). Those who have the resilience make the issue as a challenge rather than a barrier or a problem to them. This is in line with Bland et al. (1994) emphasizing the importance of research on the resilience of smart students. According to him, although resilience is seen synonymous with smart students but also among these groups who have no resilience. While, Pfeiffer \& Stocking (2000) who argue that although the GTS is a clever and very talented person in academics they are also experiencing pain, difficulty and a poor psychological level. As the findings of the study on female students by Kline and Short (1991) have found that the resilience of the students is diminishing as the course shifts. He also revealed the higher the emotional problems the lower the level of resilience. In addition, Pfeiffer \& Stocking (2000) also stressed to not consider this group as a good person in terms of social and emotional management instead those who are more in need of healthy social and emotional development which is the most important element of development and satisfaction themselves.

Obviously, resilience is a very demanding ability especially among GTS. Resilience evolves from time to time and the capabilities or capacities that appear in individuals are in the form of 
INTERNATIONAL JOURNAL OF ACADEMIC RESEARCH IN PROGRESSIVE EDUCATION AND DEVELOPMENT

Vol. 7, No. 4, 2018, E-ISSN: 2226-6348 @ 2018 HRMARS

skills. This skill will eventually become a lasting power and become part of the individual's self. In addition, resilience and decision making skills are relevant to each other (Coscun et al., 2014).

\section{Purpose of Study}

Based on the above discussion, the study aims to provide a module of Cognitive Behavior Play Therapy on Decision Making Skills and Resilience Enhancement or known as CBPT Module.

\section{Methodology}

Collecting information through library readings includes making references from books, theses and related journal articles was conducted to assist in the determination of module contents. This approach is appropriate for obtaining sufficient information in order to justify the correct and appropriate with the scope of the study which is the preparation of the module play therapy modules that involve aspects of decision making skills and resilience.

\section{Cognitive Behavioural Play Therapy (CBPT)}

CBPT is an adaptation and modification of Cognitive Theory (CT) as conceptualized by Aaron Beck's $(1964,1976)$. About 50 years ago, Aaron Beck created an innovation in psychotherapy by introducing CT. This theory has expanded and applied extensively to diverse populations. Among the issues that are often addressed using CT are depression, concern, personality issues and medical issues.

In addition, Aaron Beck developed a concept about the importance of the belief system and thought in determining behavior and feelings (Knell, 1998). In other words, an individual's understanding of an event determines how the individual's behavior and feelings are. In addition, Beck (1976) also stressed that one's emotional experience was determined by cognitive formation from the beginning. Therefore, it is very important to ensure that every individual has a healthy cognitive beginning since small.

Basically, CT has been influenced by the writings of Albert Ellis in relation to REBT. Both approaches have similarities where they focus on the wrong beliefs of the client. The CT approach is also effective for adults and it is a short-term structured approach that uses active collaboration between clients and therapists to achieve therapeutic goals. In addition, this therapy is oriented to the present problem and focuses on deviant thinking. Subsequently, using certain techniques can alter maladaptive thinking. CT approaches are not appropriate for children as the cognitive and verbal aspects of children have not been fully developed and do not allow CT to provide effective benefits to children. Hence, without any change and adaptation, this theory is not suitable for children and adolescents (Knell, 1998).

Therefore, in order to make CT effectively and successfully applied to children then some adaptations and changes have been made. Play elements have been combined with CT to align with the limited stage of child development. This is also suggested by clinicians that child intervention should involve play in connecting children with traditional verbal based interventions (Knell, 1998). The developmental stage of the child is not yet perfect, especially from the aspect of cognitive development cause CT approach is not suitable to apply to this 
INTERNATIONAL JOURNAL OF ACADEMIC RESEARCH IN PROGRESSIVE EDUCATION AND DEVELOPMENT

Vol. 7, No. 4, 2018, E-ISSN: 2226-6348 @ 2018 HRMARS

group. This is because children are not able to distinguish between rational and irrational as well as logical and non-logical thinking which an important requirement in CT applications. Hence, some changes have been made to the way CT is delivered to suit the needs of children. Then formed the Cognitive Behavioral Playing Therapy (CBPT).

According to CT's developmental history of children, a combination of CT and play therapy is unsuitable. However, in the mid-1980s, Phillips (1985) highlighted the proposed mix of cognitive and behavioral techniques in play interventions which in turn led to Knell's idea of expanding it. As a result, a new approach from adaptation from CT to child use has been named as CBPT involving a combination of cognitive, behavioral and play therapy.

\section{Decision Making Approach}

John Adair (2009) has put forward a common approach to decision making. The five-step approach is a really useful approach when one decides. The five steps stated by Adair (2009) are as follows:

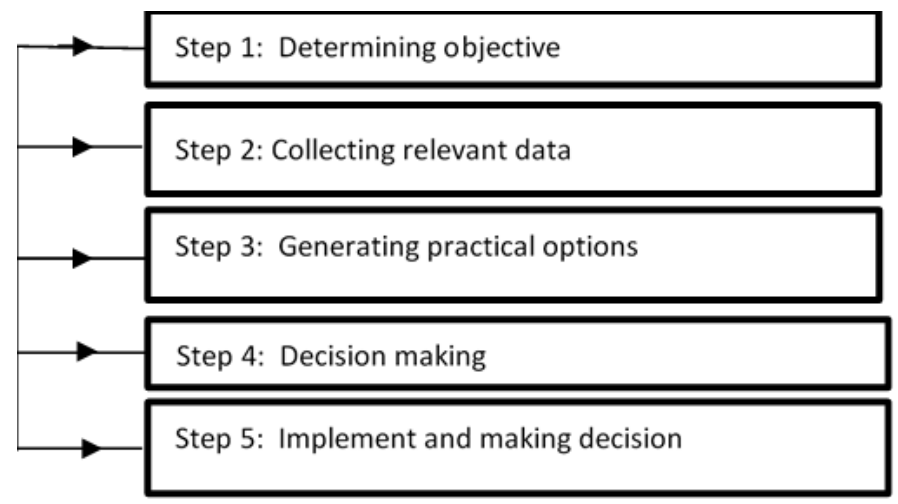

Figure 1: Decision making approach (Adair 2009)

Based on Figure 1, the first step of the usual approach in the decision-making process is to determine objectives. Adair (2009) states that one must ensure that the purpose of his purpose is in advance to get a clear picture on the whole process. Second is gathering relevant information. This step involves the action of reviewing, filtering and collecting existing information and then taking steps to retrieve the information that is left but relevant to what is being considered. Next, generate a practical option. Adair (2009) has differentiated substitute words with alternative words. An alternate word which means one of two ways that can be used has a very different meaning with the substitute words. In choosing substitute word, it involves a particular selection sequence that begins with possible criteria, practical options, three options, alternatives (two options) and finally is the chosen action. Then, set the selection criteria. The selection criteria are divided into several priority stages which are the must-be level, required level and possible level'. Adair also noted that decision makers should assess the risks and impacts of their actions before a decision is taken. The last step is to implement and make a choice. Adair (2009) presents the concept of Point of No Return (PNR). PNR is a point or word that indicates that decision makers will bear higher costs if he reverses or alters his mind rather than proceed with the decision that has now been made known that it is not a perfect decision. 


\section{Resilience Theory}

This resilience theory was introduced by Wolin and Wolin (1993). This theory has outlined some of the factors that force individuals to continue to rise to face life challenges. These factors are as follows:

\section{a. Insight}

According to this approach, insight refers to individual habits of self-esteem and attempts to honestly answer the problems faced. At the level of children, insight is formed through the ability of the feeling (ie sense), the preverbal intuition in which the child can feel something that is not here in his environment. When children get into the teenage environment, the insight element will become sharper and change to the know-how. At this stage, they began to realize and confess the problems faced.

b. Independence

Independence refers to the ability of children to separate themselves emotionally and physically from the source of the problem. Children will know and avoid themselves when they know something is getting closer. As teenagers grow, they are more capable of separating emotions from complicated problem situations and trying to be able to defend themselves when necessary.

c. Relationship

It refers to a close and meaningful relationship between certain individuals within its environment. In childhood, relationships are seen as the ability of children to engage in relationships with those who provide emotional support to them. When entering adolescence, they will be able to choose their own friends or adults who are able to give them moral help and support.

d. Self- initiative

Children who have self-initiative to move forward will be able to shape themselves as they wish. At the children's stage they will first explore through experimentation in the environment. When entering adolescence, they will be more focused and can choose activities that interest them and further develop their knowledge and interests.

\section{e. Creativity}

Creativity is an interdependent element of self-strength. Children can use their imagination to shape the world or the situation they imagined. Through creativity such as games, children can escape the suffering of their life. At the adolescent level, they are increasingly proficient in using creativity and humor to create aesthetic value through inner feelings and thoughts. The problem faced will be considered as a life challenge that can be solved through a more creative and fun channel 
INTERNATIONAL JOURNAL OF ACADEMIC RESEARCH IN PROGRESSIVE EDUCATION AND DEVELOPMENT

Vol. 7, No. 4, 2018, E-ISSN: 2226-6348 @ 2018 HRMARS

f. Morality

It refers to subconscious activity. With the power of self-morality, a child is able to distinguish something that is good with the bad. When they grow older, they will be able to think and act more mature.

\section{Module Development Model}

According to Sidek Mohd Noah \& Jamaludin Ahamad (2005) the development of a good module should take into account the various rules and procedures to produce the best effect. Rules and procedures are the basis of building a module to ensure that the module is based on a valid and reliable source. Some researchers have introduced modular modules such as Sharifah AlwiahAlsagoff (1981), Russell (1974), Design and Development Research -DDR (Richey, Klein \& Nelson, 2004) and Sidek's Module Development Model (SMDM) (Sidek Mohd Noah \& Jamaluddin Ahmad, 2005). In the context of this study, researchers will use the SMDM as the basis for the development of this study module. SMDM was introduced in 2001 as a module development procedure either in the form of training or academic (Sidek Mohd Noah \& Jamaluddin Ahmad, 2005). Many researchers who have developed the module in the field of counseling using SMDM such as Mohd Izwan et al., (2017); Md Noor Saper et., Al (2016); Amalia Madihie \& Sidek Mohd Noah (2013). Figure 2 describes the development process of the SMDM module which proposes two phases namely the phase of the module draft preparation and the phase of testing and evaluating the module: 
INTERNATIONAL JOURNAL OF ACADEMIC RESEARCH IN PROGRESSIVE EDUCATION AND DEVELOPMENT

Vol. 7, No. 4, 2018, E-ISSN: $2226-6348$ @ 2018 HRMARS

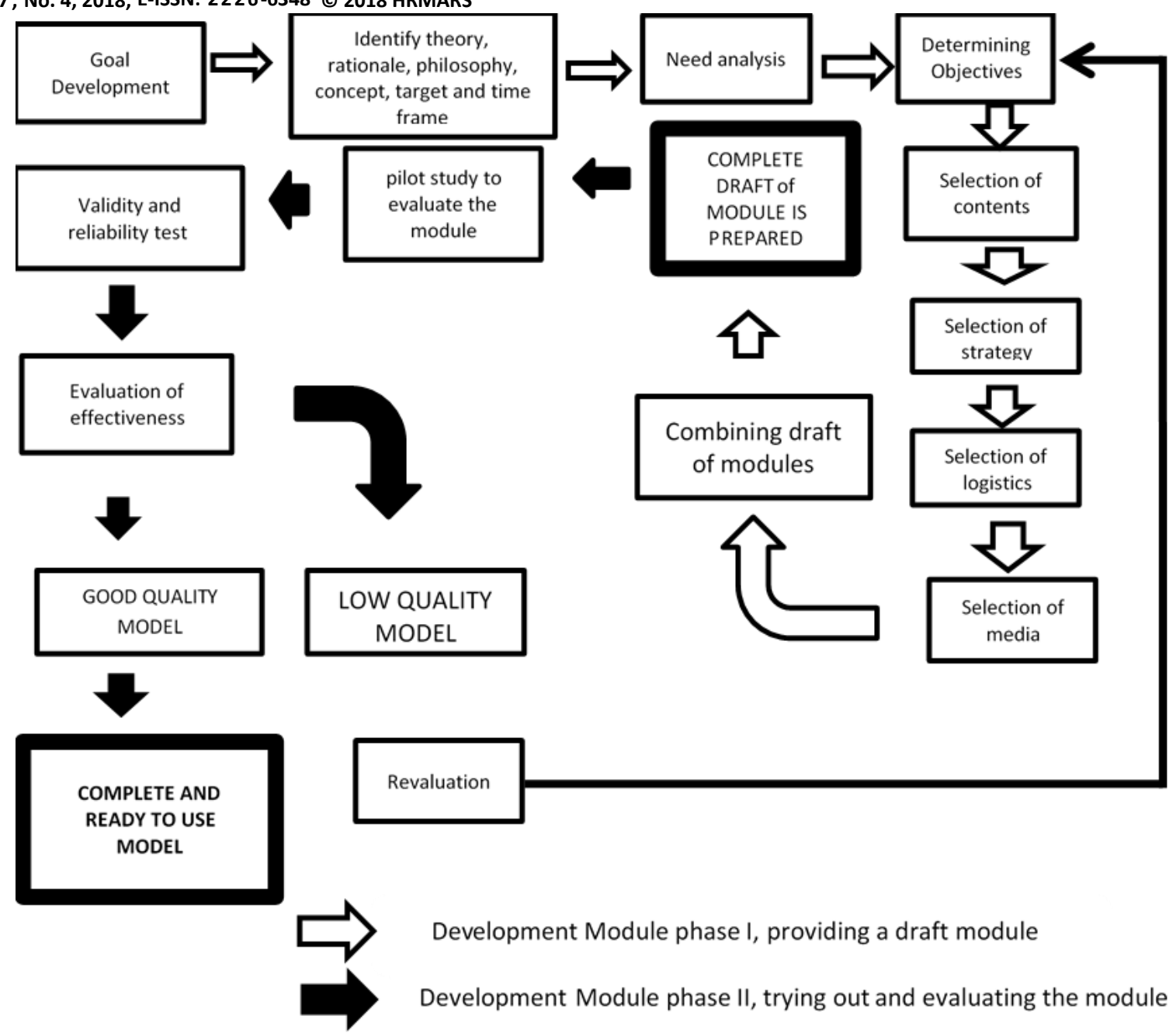

Figure 2: Sidek Module Development Model

The development process of the module based on SMDM is carried out in the first phase of the preparation of the module draft. Table 1 shows each stage in this phase is explained through the implementation steps. 
INTERNATIONAL JOURNAL OF ACADEMIC RESEARCH IN PROGRESSIVE EDUCATION AND DEVELOPMENT

Vol. 7, No. 4, 2018, E-ISSN: 2226-6348 @ 2018 HRMARS

Table 1: Development Process of CBPT Module Based on First Phase Preparation of the Module Draft.

\begin{tabular}{|c|c|}
\hline Stages & Steps \\
\hline $\begin{array}{l}\text { Goal } \\
\text { development }\end{array}$ & $\begin{array}{l}\text { The goal of building this module is to intervene to the Muslim GTS that has social and } \\
\text { emotional issues. In the process of building goals, the results of the need analysis to be } \\
\text { used. Among the needs analysis findings show that the module needs a creative approach } \\
\text { in line with the affective nature of the GTS. Hence, the goal is aimed at producing creative } \\
\text { approaches with techniques in play therapy. }\end{array}$ \\
\hline $\begin{array}{l}\text { Identify theory, } \\
\text { rationale, } \\
\text { philosophy, } \\
\text { concept, target } \\
\text { and time frame }\end{array}$ & $\begin{array}{l}\text { Identifying related theories such as Decision-Making Approach, Resilience Theory and } \\
\text { CBPT because these theories describe the variables measured in accordance with the } \\
\text { problems faced by the GTS. In addition, Decision-Making and Resilience Theory also } \\
\text { explains the concepts and appropriate interventions to measure the decision-making skills } \\
\text { and resilience of the students. CBPT is used as the basis for the development of modules } \\
\text { as well as the activities available in the modules. }\end{array}$ \\
\hline Need analysis & $\begin{array}{l}\text { Need analysis study are conducted to identify module development requirements. In this } \\
\text { study, the needs analysis study was conducted through the interview method. A total of } 4 \\
\text { counselors involved with the GTS were interviewed. The findings explain that there is a } \\
\text { need to build modules that are in line with GTS affective developments in order to improve } \\
\text { GTS skills and abilities }\end{array}$ \\
\hline $\begin{array}{l}\text { Determining } \\
\text { objectives }\end{array}$ & $\begin{array}{l}\text { Objectives are divided into two which are general objective and specific objectives. The } \\
\text { general objective is to describe the overall objectives that will be achieved in the } \\
\text { implementation of the module. While the specific objective is the purpose of each sub } \\
\text { module or activity being implemented. }\end{array}$ \\
\hline $\begin{array}{l}\text { Selection } \\
\text { contents }\end{array}$ & $\begin{array}{l}\text { Content will be built and selected based on Decision-Making Approach, Resilience Theory } \\
\text { as each activity is able to explain the variables. In addition, the selection of content will } \\
\text { also affect the objectives of each activity. For example, based on the Decision-Making } \\
\text { Approach there are } 5 \text { steps in making decisions while based on Resilience Theory there } \\
\text { are } 7 \text { strengths that exist in a resilient individual. Choosing the appropriate content will be } \\
\text { based on the domain. In addition, each activity is conducted using the techniques found } \\
\text { in CBPT. }\end{array}$ \\
\hline $\begin{array}{l}\text { Selection } \\
\text { strategy }\end{array}$ & $\begin{array}{l}\text { The choice of strategy will take into account the level of facilitator understanding, the } \\
\text { suitability of the participants, the location or place of the program, and the timing of the } \\
\text { meeting. All these factors will be taken into account to determine the smooth } \\
\text { implementation of the module and thus impact on the effectiveness of the module. }\end{array}$ \\
\hline $\begin{array}{l}\text { Selection } \\
\text { logistics }\end{array}$ & $\begin{array}{l}\text { The logistics selection includes the materials to be used in each activity, the suitability of } \\
\text { the location or the place of the program, facilitator training, and participants' safety. } \\
\text { Researchers will provide a manual checklist to ensure that the logistics requirements are } \\
\text { satisfactory and meet the criteria to be set. }\end{array}$ \\
\hline $\begin{array}{l}\text { Selection } \\
\text { media }\end{array}$ & $\begin{array}{l}\text { The module delivery method will take into account the need for activities that combine } \\
\text { several medium delivery methods such as group training, role play and presentation. In } \\
\text { addition, teaching aids such as video clips, music, and therapeutic play equipment such as } \\
\text { clay, color pencil, sand will be used to attract participants actively involved in every } \\
\text { activity. }\end{array}$ \\
\hline $\begin{array}{l}\text { Combining draft } \\
\text { module }\end{array}$ & $\begin{array}{l}\text { Drafts of completed modules will be collected and streamlined for each activity in order. } \\
\text { The module development phase of the module is complete and will be through the second } \\
\text { phase of testing and evaluating the module. }\end{array}$ \\
\hline
\end{tabular}

\section{Cognitive Behavior Play Therapy on Decision Making Skills and Resilience Enhancement (CBPT Module)}

The CBPT module draft is drafted and provided based on CBPT, decision-making domains and resilience domains. The draft preparation is based on the modality of play therapy which is also 
INTERNATIONAL JOURNAL OF ACADEMIC RESEARCH IN PROGRESSIVE EDUCATION AND DEVELOPMENT

Vol. 7, No. 4, 2018, E-ISSN: 2226-6348 @ 2018 HRMARS

known as the sub module. Meanwhile, 5 domains of decision making by Mincemoyer \& Perkins (2003) which are 'defining problems, generating alternatives, checking risks and consequences, choosing alternatives, evaluating results' and 7 domains of resistance by Biscoe and Hariss (1994) which are 'insight, independence, relationships, self- initiatives, creativity and humor, morality and general resilience' have been combined through customization processes based on the definition of each domain. It has subsequently resulted in 5 combined domains namely 1defining problems and literacy, 2- generating alternatives, checking risks, choosing alternatives and evaluating results, 3- relationships and self-reliance, 4-creatives and humor and initiative as well as 5- morality and general resilience or also known as a unit in this module. The unit produced 14 activities as a whole. Presentation of all activities is carried out using techniques in CBPT which is modeling and delivered through techniques such as behavioral exercises, coping self-statements, bibliotherapy and systematic desensitization. Each unit relates to the next unit or in other words all units are dynamically occurring processes.

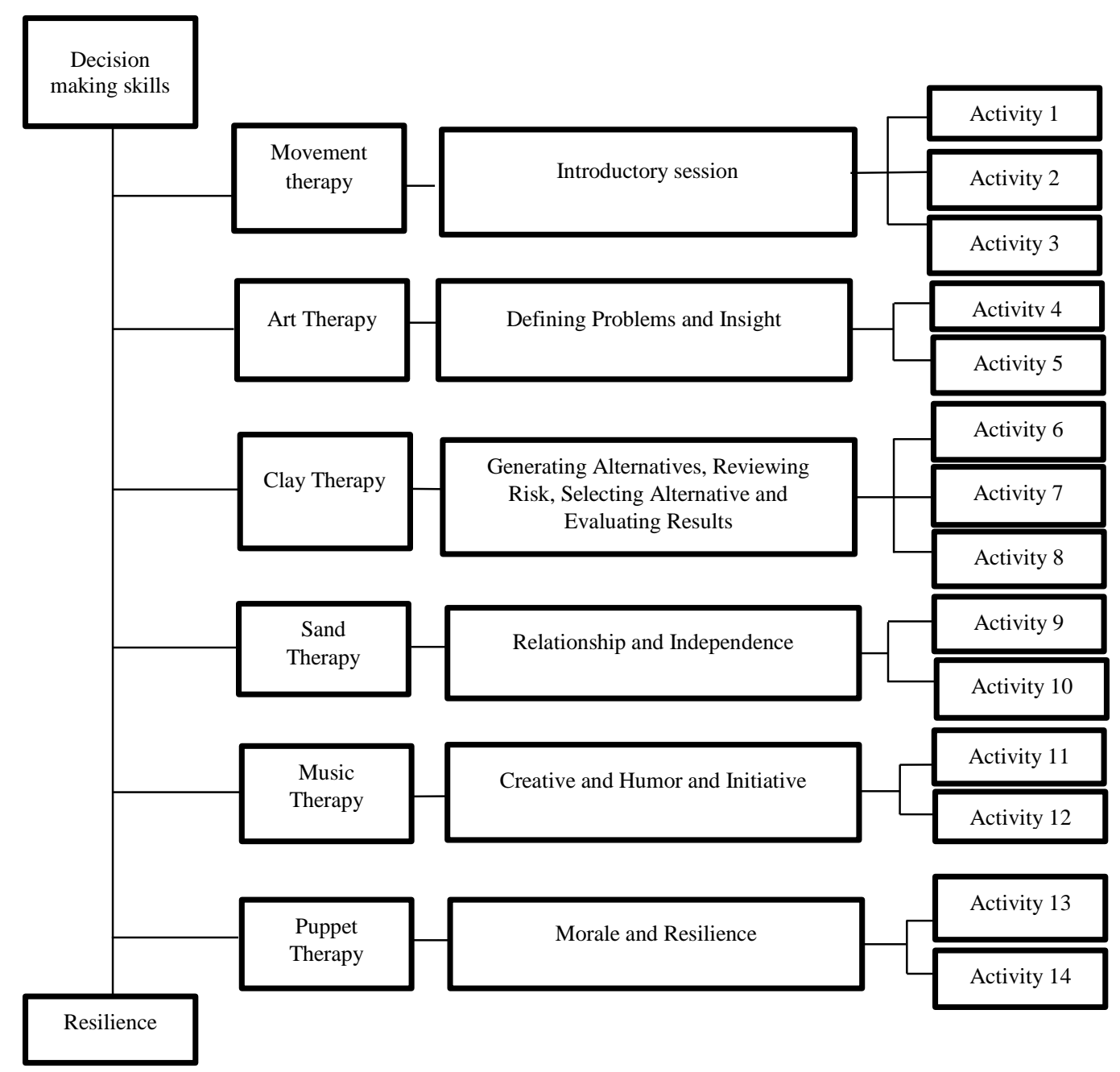

Figure 3: Cognitive Behavior Play Therapy on Decision Making Skills and Resilience Enhancement (CBPT Module) 


\section{Sub Module of Movement Therapy}

The movement therapy sub module is used as an introductory session. Movement therapy focuses on behavioral movements as it appears in therapeutic relationships that allow children to develop positive and realistic self-image. This therapy was chosen as the modality for the introduction session as it was found to be effective in stimulating social interaction, improving mood, reducing anxiety and anxiety and raising self-awareness as well as self-expression (Koch et al., 2014). In addition, movement therapy also helps keep attention and focus apart from functioning as a catalyst for relationships and paving the way for communication (Levine, Land \& Lizano, 2015).

Overall, sub module of movement therapy was produce three activities organized and require participants to move actively and can help participants be clear and willing to engage throughout the session. The first activity involves warming up the body, the second activity is identification and the third activity is related to understanding the roles and rules throughout the session.

\section{Sub Module of Art Therapy}

Sub module of art therapy consist of units defining problems and insight. Art therapy is defined as a form of therapy that uses color media, pencils and markers integrated with therapeutic psychotherapy and creative process techniques. Art therapy is also a way to encourage clients to express their feelings and thoughts that can not be born with words through art especially paintings. Through artistic expression the client can understand how to expose internal needs and soul conflicts and can provide assistance in seeking resolution.

While the unit of defines the problem and insight refers to the ability to understand the issues in-depth and take action. To measure the ability, there are two activities to be built. Activity 4 was built to measure the theme 'responding, interpreting, addressing issues and strengths in addressing questions and giving answers honestly. In addition, activity 5 is to measure the theme of 'ability to organize, break down, creatively and choose and collaborate with others.' In general, the art therapy sub module produces 2 organized activities that can measure the ability to define the problem and the students' insight. This process requires creative activities such as the use of media aids and also in the form of sharing experience and knowledge.

\section{Sub Module of Clay Therapy}

Sub modules of clay therapy consisting the unit of generating, checking risks, choosing alternatives and evaluating results. Generally, this unit refers to a decision making process that involves the consideration of positive and negative effects of a decision, identifying better options and prioritizing choices before making decisions and comparing past choices when making new decisions and making positive changes. There are 3 activities built to meet these themes. Activity 6 to measure the ability to find new information, get alternative sources, explain facts and make judgments. Activity 7 is to measure the ability to analyze options, to identify advantages and disadvantages of options, to interpret results of a decision and to choose the right choice. While activity 8 is to measure the ability to differentiate and define information, 
DEVELOPMENT

Vol. 7, No. 4, 2018, E-ISSN: 2226-6348 @ 2018 HRMARS

review, to stay firm on stand and give basic principles. All activities are coincidental with sub modules of clay therapy where this therapy involves the use of muscular limbs such as eyes and hands that can make the participants more focused. For example, activity 8 is where students need to create a snail using clay based on the given roles. The activity requires students to be aware of the role that each member employs with respect to the creation of a snail.

\section{Sub Module of Sand Therapy}

The sand therapy sub modules are comprised the unit of relationships and independence. The unit refers to the ability of the student to initiate and maintain the relationship of intimacy and bond with others as well as the ability of the individual to place a safe boundary between themselves and others in order to maintain relationships and to pursue relationships. Based on the theme 2 activities have been developed based on sand therapy.

Sand therapy sand therapy is a therapeutic psycho technique that allows clients to assemble small objects in sandboxes and build 'sand world' according to their real world dimensions. It is also an expressive and dynamic process where self-awareness, emotional and communication experiences are enhanced through this process.

\section{Sub Module of Music Therapy}

Music therapy is an activity that uses music or vocal instruments. This therapy is effective in alleviating pain and anxiety, managing stress, communication and emotional distress.

The music therapy sub modules for this module consist of creativity \& humor skills and self-initiative unit. This unit is to bring the ability to use creativity to forget about the pain, the creative in problem solving, and the use of humor to reduce stress or make the situation worse and excitedly describe how something happened. To measure this theme, 2 activities were built. This process requires creative activities such as the use of media aids, presentations and even forms of sharing experience and knowledge.

\section{Sub Module of Puppet Therapy}

The puppet therapy sub module consists of moral and general resilience unit that refers to knowing what is right and wrong, holding on to beliefs, joy of helping others, persisting in difficulties, belief that one can take advantage from bad situation and confidence that one can do something right. 2 activities were built to measure the theme. Activity 13 is where student students learn the right and wrong things, assess the firmness of the faith and are willing to face the risk and work hard through the reading of the story book that is performed by the puppets. Meanwhile, activity 14 is a student performing a show about 'helping each other' using puppet.

\section{Summary and Suggestion}

The development of the CBPT module discussed in this article has produced a draft of 6 sub modules and 14 activities as a whole. While SMDM is suitable as a foundation in the development of this module as it has structured levels. The development of the module using the SMDM can help researchers to plan, devise and organize systematic measures. This model is considered complete as it can explain the construction of module until to test the effectiveness of the 
INTERNATIONAL JOURNAL OF ACADEMIC RESEARCH IN PROGRESSIVE EDUCATION AND DEVELOPMENT

Vol. 7, No. 4, 2018, E-ISSN: 2226-6348 @ 2018 HRMARS

module. The steps can be arranged according to the sequence of each phase and phase to ensure the quality of the module (Sidek Mohd Noah \& Jamaluddin Ahmad, 2005). By setting the theories and variables to be used, researchers are assisted in generating objectives in general and specific according to the themes in each sub module. Therefore, the development of a good training module should be based on the appropriate module development model.

Previous studies that examine social and emotional issues among GTS (Rorlinda et al, 2016; Noriah and Abu Yazid, 2014; Blaas, 2014; Abu Yazid and Noriah, 2010) and decision-making skills application (Fallis, 2013) and resilience (Cazan \& Dumitrescu, 2016) can explain how the decision making skills and resilience are able to address the social and emotional issues faced (Diker, \& Tosun 2014) and how these skills and abilities can be improved through appropriate interventions. While previous studies pertaining to the development of modules have been implemented as one of the most appropriate interventions to address social and emotional issues among GTS (Rafidah, 2013; Walden et al., 2007; Gross, 2004; Bailey, 2003).

Because GTS is inseparable with social and emotional issues as it involves the special features of the student itself, the counseling program should play an active role in efforts to improve the GTS decision-making and resilience. However, the approach used should suit their needs. It is clear that play therapy is the most appropriate approach because creative elements are compatible with the GTS features themselves. However, play therapy is a new approach and most counselors have not mastered this approach in depth.

Hence, an effort to assist and guide counselors in providing counseling services to GTS is through the implementation of these services assisted with structured modules based on play therapy. The next study should focus on the contents validity and reliability of the CBPT module that have been prepared and discussed in this article.

\section{Corresponding Author}

Ku Suhaila Ku Johari,

Community Well-being \& Education

Faculty of Education

Universiti Kebangsaan Malaysia

Email: suhaila@ukm.edu.my

\section{References}

Adair, J. (2009). Membuat Keputusan Dan Strategi Menyelesaikan Masalah. Terj. Amir Muslim. Kuala Lumpur: Institut Terjemahan Negara Malaysia.

Amini, M. (2005). Identifying Stressors and Reactions to Stressors in Gifted and Non-Gifted Students. International Education Journal, 6(2), 136-140.

Axline, V. M. (1969). Play Therapy. New York: Ballantine Books. 
INTERNATIONAL JOURNAL OF ACADEMIC RESEARCH IN PROGRESSIVE EDUCATION AND DEVELOPMENT

Vol. 7, No. 4, 2018, E-ISSN: 2226-6348 @ 2018 HRMARS

Ball, C., Mann, L., \& Stamm, C. (1994). Decision-Making Abilities of Intellectually Gifted, Australian Journal of Psychology, 46(1), 13-20.

Biscoe, B. \& Harris, B. (1994). The Resiliency Attitude Scale Manual. Oklahoma City: Eagle Ridge Institute, Inc.

Blaas, S. (2014). The Relationship Between Social-Emotional Difficulties and Underachievement of Gifted Students. Australian Journal of Guidance and Counselling, 24(02), 243-255.

Bland, L. C. Sowa, C. J., \& Callahan,C. M. (1994). An Overview of Resilience in Gifted Children. Roeper Review, 17(2), 77-80.

Bratton, S. Ray, D.,Rhine, T. \& Jones, L. (2005). The Efficacy of Play Therapy with Children: A MetaAnalytic Review of Treatment Outcomes. Psychology Research and Practice, 36(4), 376-390.

Beck, A. T. (1964). Thinking and depression. Part 2: Theory and therapy. Archieves of General Psychiatry, (10), 561-571.

Beck, A. T. (1976). Cognitive therapy and the emotional disorders. New York, NY: International Universities Press.

Cazan, A., \& Dumitrescu, S. A. (2016). Exploring The Relationship Between Adolescent Resilience, Self-Perception and Locus of Control. Romanian Journal of Experimental Applied Psychology, 7(1), 283-286.

Colakkadioglu, O., \& Celik, B. (2016). The Effect of Decision-Making Skill Training Programs on Self-Esteem and Decision-Making Styles. Eurasian Journal of Educational Research, 65, 259-276.

Coskun , Y.D., Garipağaoğlu, C., \& Tosun, Ü. (2014). Analysis of the Relationship between the Resiliency Level and Problem Solving Skills of University Students, Procedia - Social and Behavioral Sciences, 114, 673-680.

Chen, X., Cheung, H. Y., Fan, X. \& Wu, J. (2017). Factors related to resilience of academically gifted students in the chinese cultural and educational environment. Psychology in the Schools, (1), 113.

Davidson, J., \& Sternberg, R. (1984). The Role of Insight in Intellectual Giftedness. Gifted Child Quanterly, 28, 58-64.

Devall, Y. (1983). Some Cognitive and Creative Characteristics and Their Relationship to Reading Comprehention in Gifted and Non-Gifted Fifth Graders. Journal for the Education of the Gifted, 5, 259-273. 
INTERNATIONAL JOURNAL OF ACADEMIC RESEARCH IN PROGRESSIVE EDUCATION AND DEVELOPMENT

Vol. 7, No. 4, 2018, E-ISSN: 2226-6348 @ 2018 HRMARS

Ersoy, E., \& Deniz, M. E. (2016). Psychometric Properties of the Gifted Students' Coping with Anger and Decision Making Skills Scale. Journal of Education and Practice, 7(15), 121-128.

Fallis, A. (2013). Emotions and Decision Making. Annual Review of Psychology, 53(9), 1689-1699.

Frederickson, B. L. (2004). The Broaden-and-Build Theory of Positive Emotions. Philosophical Transactions of the Royal Society, 359, 1367-1377.

Fehrenbach, C. R. (1991). Gifted Average Readers: Do They Use the Same Reading Strategies? Gifted Child Quaterly, 35, 125-1 27.

Gagne, F. (2009, January). Building Gifts into Talents: Brief Overview of The DMGT 2.0. Retrieved from

https://www.researchgate.net/publication/287583969_Building_gifts_into_talents_Detailed_o verview_of_the_DMGT_20

Gallagher, J. J., \& Gallagher, S. A. (1994). Teaching the gifted child (4th ed.). Boston, MA: Allyn

Greenbank, P. (2010). Developing Decision-making Skills in Students: An Active Learning Approach. Teaching and Learning Development Unit Edge Hill University.

Klaczynski, P. A., Byrnes, J. B., \& Jacobs, J. E. (2001). Introduction: Special Issue on Decision Making. Journal of Applied Developmental Psychology, 22, 225-236.

Kline, B. E., \& Short, E.B. (1991). Changes in emotional resilience: Gifted adolescent females. Roeper Review, 13(3), 118-121.

Knell, S. M. (1998). Cognitive-Behavioral Play Therapy. Journal of Clinical Child Psychology. 27(1): 28-33.

Knell, S. M. (2009). Cognitive-Behavioral Play Therapy. Northvale, NJ: Jason Aronson Inc.

Kuet, C. T. (2014). Penggunaan Terapi Bermain Pasir Dalam Menangani Masalah Perhubungan Sosial Antara Rakan Dan Ahli Keluarga Murid Tahun Tiga. Jurnal Penyelidikan Tindakan, (8), 1-17.

Koch, S., Kunz, T., Lykou, S., \& Cruz, R. (2014). Effects of dance movement therapy and dance on health-related psychological outcomes: A meta-analysis. Arts in Psychotherapy, 41(1), 46-64.

Levine, B., Land, H. M. \& Lizano, E. L. (2015). Critical Social Work the Elements of Dance/Movement Therapy Employed when Treating Women with Posttraumatic Stress Disorder. Critical Social Work, 16(1). Retrieved from

http://www1.uwindsor.ca/criticalsocialwork/DancemovementTherapy 
INTERNATIONAL JOURNAL OF ACADEMIC RESEARCH IN PROGRESSIVE EDUCATION AND DEVELOPMENT

Vol. 7, No. 4, 2018, E-ISSN: 2226-6348 ๑ 2018 HRMARS

Landreth, G. L. (2002). Play Therapy: The Art of the Relationship (2nd ed). New York: Psychology Press.

Mahoney, A.S. (2011, September 13). The Gifted Identity Formation Model: In Search of the Gifted Identity, From Abstract Concept To Workable Counseling Constructs. Retrieved from http://sengifted.org/the-gifted-identity-formation-model-in-search-of-the-gifted-identity-fromabstract-concept-to-workable-counseling-constructs/

Mariani, M., \& Asnarulkhadi, A. S. (2016). Pelaksanaan Terapi Bermain Ke atas Kanak-kanak Peringkat Awal yang Mengalami Stres. E-Proceeding of the 3rd World Conference on Integration of Knowledge. Langkawi, Malaysia.

Mak, W.W.S., Ng, I. S.W., \& Wong, C. C.Y. (2011). Resilience: Enhancing Well-Being Through the Positive Cognitive Triad. Journal of Counseling Psychology, 58(4), 610-617.

Marr, D., \& Sternberg, R. (1986). Analogical Reasoning with Novel Concepts: Differential attention of intelectually gifted and non- gifted children to relevant and irrelevant novel stimuli. Cognitive Development, 1, 53-72.

Masureik, N., Roman, N. V., Roman, N. J., \& Toefy, A. (2014). Stress, Anxiety Levels and Decision Making Styles of South African Senior Learners: Results of a Science Fair Project. International Journal of Education, 6(3), 57.

Miller, D. C., \& Byrnes, J. P. (2001). Adolescents' decision making in social situations: A selfregulation perspective. Applied Developmental Psychology, 22, 237-256.

Milligan, J. (2004). Leadership Skills of Gifted Students in a Rural Setting: Promising Programs for Leadership Development. Rural Special Education Quarterly, 23(1), 16-21.

Mincemoyer, C.C., \& Perkins, D.F. (2003). Assessing decision making skills of youth. The Forum for Family and Consumer Issues (FFCl) 8(1). Retrieved from

http://ncsu.edu/ ffci/publications/2003/v8-n1-2003- january/ar-1-accessing. Php.

Miraca U.M. Gross (2004). Gifted and talented education profesional development package for teachers module 3. Gifted Education Research, Resource and Information Centre (GERRIC), The University of New South Wales (UNSW).

Mofield, E., Parker Peters, M., \& Chakraborti-Ghosh, S. (2016). Perfectionism, Coping, and Underachievement in Gifted Adolescents: Avoidance vs. Approach Orientations. Education Sciences, 6(3), 21.

Neihart, M., Reis, S., Robinson, N., \& Moon, S. (2002). The social and emotional development of gifted children: What do we know? Waco, TX: Prufrock Press. 
INTERNATIONAL JOURNAL OF ACADEMIC RESEARCH IN PROGRESSIVE EDUCATION AND DEVELOPMENT

Vol. 7, No. 4, 2018, E-ISSN: 2226-6348 @ 2018 HRMARS

Neihart, M. (2002). Risk and resilience in gifted children: A conceptual framework. In M. Neihart, S. Reis, N.M. Rob- inson, \& S.M. Moon (Eds.), The social and emotional development of gifted children: What do we know? (pp. 113-124). Waco, Texas: Prufrock Press, Inc.

Ogurlu, U., Kaya, F., \& Hizli, E. (2015). Career Decisions of Gifted Students in Turkey, Jurnal of European Education, 5(1), 31-45.

Ozcan, D. (2017). Career Decision-Making of The Gifted and Talented South African. Journal of Education, 37(4), 1-8.

Perrone-McGovern, K. M., Simon-Dack, S. L., Beduna, K. N., Williams, C. C., \& Esche, A. M. (2015). Emotions, Cognitions, and Well-Being. Journal for the Education of the Gifted, 38(4), 343-357.

Pfeiffer, S. I., \& Stocking, V. B. (2000). Vulnerabilities of academically gifted students. Special Services in the Schools, 16(1-2), 83-93.

Rafidah Kastawi, \& Noriah Mohd Ishak. (2013). Terapi seni dalam kaunseling pelajar pintar dan berbakat. Malaysian Journal of Youth Studies, 8(6), 147-166.

Rehman, R. R., \& Khan, A. W. (2015). Realting individual demographics, work- family conflict and decision making styles of faculty members in higher education sector of Pakistan. VFAST Transections on Education and Social Sciences, 5, 51-63.

Richey, R.C., Klein, J.D., \& Nelson, W. A. (2004). Developmental research: Studies of instructional design and development. Retrieved from http://www.aect.org/edtech/41.pdf

Russell, J.D. (1974). Modular instruction: A guide to the design, selection, utilization and evaluation of modular materials. Minneapolis, MN: Burgess.

Yusof, R. (2014). Ciri- ciri Kepimpinan Pelajar Pintar dan Berbakat: Implikasi Ke Atas Kepimpinan Remaja Islam. International Journal of Islamic Thought, 6, 57-70.

Saygili, G. (2014). Problem-Solving Skills Employed by Gifted Children and Their Peers in Public Primary Schools in Turkey. Society for Personality Research, 42, 53-64.

Nen, S. (2014). Perlindungan Kanak-kanak. Institut Sosial Malaysia. Kementerian Pembangunan Wanita, Keluarga dan Masyarakat. Disember,8-11.

Schlichter, C.L. (1981). Decision Making: An Instructional Strategy for the Rural Gifted Student. Retrieved from http://files.eric.ed.gov/fulltext/ED220257.pdf

Scott, M. T. (2012). Socio-Emotional and Psychological Issues and Needs of Gifted AfricanAmerican Students: Culture Matters. Interdisciplinary Journal of Teaching and Learning, 2, (1), 23-33. 
Alsagoff, S. A. (1981). Pengenalan pengajaran individu dengan tumpuan khas kepada modul pengajaran dan modul pembelajaran. Jurnal Pendidik dan Pendidikan. 3(1), $54-62$.

Taal, M., \& De Carvalho, F. S. (1997). Stimulating Adolescents Decision Making. Journal of Adolescence, 20, 223-226.

Touron, J., Touron, Silvero, M. (2005). The Center for Talented Youth Spain: An initiative to serve highly able students. High Ability, 15, 121-135.

Versteynen, L. (2013). Issues in The Social and Emotional Adjustment of Gifted Children: What Does The Literature Say?. The New Zealand Journal of Gifted Education,13 (1).

Walden, P.G., Caudill,G., Lovell,C., Rawlins, S. (2007). Guidance and Counseling for the Gifted. Guidance and Counseling for the Gifted. Clearinghouse Information Center, Bureau of Exceptional Education and Student Services, K-12 Public Schools, Florida Department of Education

Wolin, S. J., \& Wolin, S. (1993). The Resilient Self. New York: Random House. 